\title{
Oil palm: Domestication achieved?
}

\section{W. GERRITSMA ${ }^{1 . *}$ AND M. WESSEL 2}

1 Wageningen Agricultural University, Department of Agronomy, Haarweg 333, NL 6709 RZ Wageningen

2 Wageningen Agricultural University, Department of Forestry, Generaal Foulkesweg 64, NL 6703 BV Wageningen

* corresponding author (fax: +31-317-484575; e-mail: wouter.gerritsma@users.agro.wau.nl)

Received: 11 August 1997; accepted 31 December 1997

\begin{abstract}
The natural habitat of the oil palm comprises very wet and relatively dry niches in the lowland rain forest in West and Central Africa. The domestication of the oil palm started with the extraction of fruits from wild forest resources. When forests were cleared for shifting cultivation, oil palms were not felled and in the subsequent regeneration period they obtained a favourable position resulting in semi-wild palm groves. Thinning of groves gave rise to semi-permanent or permanent intercropping systems of palms and food crops.

After the transfer of oil palm to S.E. Asia in the 19th century, a mono-crop oil palm evolved. Its success was based on a favourable climate, breeding, improved cultivation and processing practices and the absence of major pests and diseases. The high-yielding production systems are sustainable at high input levels and pollution can be kept within acceptable limits. Oil yields and production costs compare favourably to those from other oil crops.

The domestication of oil palm for oil yield so far can be considered as a success story. Physiological studies indicate that there is still considerable scope for further increase in yield. The adaptation of oil palm to new environments will continue and produce diversification puts new demands on domestication.
\end{abstract}

Keywords: Elaeis guineensis, oil palm, domestication, plantations, smallholders, groves, breeding, cultivation, processing, sustainability.

\section{Introduction}

Oil palm (Elaeis guineensis Jacq.) provides an interesting example of the processes and stages in the transition of natural forest ecosystems to tree crop plantations. This transition, or domestication, from the collection of a forest resource product, the oil palm fruits, to the management of wild oil palm vegetations, the semi-wild oil palm groves, took place over a long period. The next step in the domestication was the establishment of well managed plantations and plantation-derived systems, first in S.E. Asia and later in West Africa as well. Loosely defined, domestication means 'to bring something into the household', in biological sciences with special reference to plants and animals. Wild plants or animals are taken from their natural habitat and 
reproduced for successive generations under man-made conditions (Seibert, 1948). Harlan (1975) described domestication as an evolutionary process. All intermediate stages of plant and animal associations with man may occur, ranging from growing almost wild races to fully domesticated ones. In his view domestication is completed when the propagation of plants or animals is entirely dependent on man for survival. Domestication often implies a change in ecological adaptation, which is usually associated with morphological differentiation. In contrast to Harlan, Johannessen (1982) pointed out that domestication is a continuing, human controlled process of genotypic modifications that has been operative since cultivation began. Evans (1993) took the definition of domestication a step further by referring not only to the adaptation of plants to the conditions of agriculture but also by including the improvement of yield potential. In our view domestication is a continuing process which started with the extraction of seeds and fruits from wild resources, continuing with adaptations of the yield potential, and quality of the crop by means of breeding, cultivation and processing. Our concept widens the traditional domestication concept further to include also the sustainability and economics of production and processing systems. The oil palm presents a good example of a crop whose yield still responds to improved environments and whose genetic potential for increased yields is not yet fully exploited. It can be argued that the full domestication ends when under prevailing yield-determining conditions, defined by radiation and temperature, potential yields are approached and production and product processing have a sustainable basis.

This paper reviews the different stages in the domestication process of oil palm, especially the adaptation to plantation agriculture and the simultaneous genetic improvement, and the prospect for reaching the full yield potential for in different environments.

\section{The oil palm in Africa}

\section{Geographic distribution}

The geographic distribution of oil palm in Africa has been summarised by Zeven (1967) and Hartley (1988). Oil palm occurs mainly in a belt parallel to the Atlantic Coast in West and Central Africa extending from Cape Verde to Angola. The palm belt is delimited in the north and south by the $1600 \mathrm{~mm}$ isohyet and on a few occasions by the topography of terrain. The deltas of the rivers Niger and Congo are characterised by dense populations of man and intense oil palm exploitation. In Central Africa the oil palm belt extends inland, covering Congo- $K$ and parts of Congo-B and Angola. The geographical distribution is continuing eastwards to the shores of the Great Lakes. Oil palms have been distributed with early slave trade to east Tanzania, and to the islands of Pemba, Zanzibar and Madagascar. The oil palm continues to spread eastward in Central Africa.

Within the oil palm belt the palm is found in its natural habitat. In general they grow at altitudes below $500 \mathrm{~m}$, but in some instances oil palms have been found 
thriving on mountains in East and West Africa up to $1700 \mathrm{~m}$. Oil palms are furthermore found on swampy river banks, in swamps, on alluvial plains and low lying river islands and in river valleys between table lands. Zeven (1967) summarised these natural habitats as those areas that are too wet for rain forest vegetation, but not too wet for the oil palm. In such areas the absence of tall trees allows enough light to reach the heliophile oil palm. The other natural habitat is the forest fringe, especially forest outliers in the Forest Savanna mosaic type. Here rainfall is limiting the dense rain forest, and oil palms are able to compete for water, light and nutrients with the sparser savanna vegetation.

\section{Oil palm groves in Eastern Nigeria}

Oil palm groves occur widespread throughout the oil palm belt of West Africa. These groves have been studied most extensively in Nigeria, where it was estimated in 1990 that about 2.8 million ha of semi-wild oil palm groves existed (Anonymous, 1996). Man is the main factor that has given rise to these (semi-wild) palm groves and to the heterogeneity of the groves in an area where the original climax vegetation was the high rain forest.

The succession of oil palm groves summarised here has been studied in detail by Zeven (1967). The oil palm is thought to have been introduced in the rain forest by hunters and shifting cultivators who left some oil palm seeds behind in the forest but especially around deserted hunting camps and compounds. In the forest generally a few palms survived and these were spared when the forest was cleared again for food cropping. At relatively low population densities and regular occupation of the land for arable food crop farming but with sufficiently long fallow periods to restore soil fertility, secondary forest becomes the predominant vegetation. The density of oil palms is low in this secondary forest (Table 1). With the cessation of farming in the area, palm stands decline as they are not capable to compete with the regenerating rain forest.

When the rotation becomes shorter and the forest is thinned more frequently for food cropping to accommodate an increased population, the palms growing up from the old compounds stand a chance to compete with the regrowing secondary forest. This is a transitional stage between 'secondary forest with palms' and 'dense groves', the so-called 'palm bush'. In the latter the palm stands are denser than in the

Table I. Semi-wild oil palm vegetation types in S.E. Nigeria. Based on Zeven (1967).

\begin{tabular}{llll}
\hline Vegetation class & $\begin{array}{l}\text { Population density } \\
\text { (persons } \mathrm{km}^{-2} \text { ) }\end{array}$ & $\begin{array}{l}\text { No. Stemmed } \\
\text { palms ha-1 }\end{array}$ & $\begin{array}{l}\text { FFB yield } \\
\left(\mathrm{t} \mathrm{ha}^{-1}\right)\end{array}$ \\
$\begin{array}{l}\text { Secondary forest with oil palms } \\
\text { Palm bush }\end{array}$ & $<75$ & 1.5 & \\
Dense grove & $15-90$ & $75-150$ & 2.0 \\
Thinned grove & $80-220$ & $125-350$ & $3.0-5.0$ \\
Sparse grove & $200-350$ & $50-100$ & $1.5-3.0$ \\
Village grove & n.d. & 40 & 1.6 \\
\hline
\end{tabular}


'secondary forest with oil palms' and they yield slightly more per unit area than the 'secondary forest with oil palms'.

Where population pressure is further increased, in some areas 'dense groves' develop, with the palms almost in pure stands with only small shrubs and shade tolerant crops between them. Due to the heavy shade, oil palms in dense groves cannot regenerate themselves. The yield of dense groves is the highest of all grove types with densities well above the recommended densities for plantations. The dense groves form the climax oil palm vegetation. Once these high densities have been obtained the grove start to degenerate.

Beyond population densities of 200 persons $\mathrm{km}^{-2}$ the land becomes overfarmed, the fallow period not being sufficiently long to restore soil fertility. The 'dense groves' are thinned to make land available for arable farming, resulting in 'thinned oil palm groves', or when the palms are dying and no replanting takes place 'farmland with or without oil palms' is the result. When compounds become permanent due to a high population density the grove is typified as a 'village grove'. The fertility of these groves is maintained with household waste, palms are kept at densities of more than 100 palms ha ${ }^{-1}$. Thinning and filling in of these groves is sometimes associated with a genetic shift in the constitution of the groves, generally resulting in relatively more tenera palms which are capable of producing higher oil yields.

Throughout these various stages yields remained very low. Attempts to improve yields of groves by selective thinning, pruning and clearing of the undergrowth have only been carried out on an experimental scale by researchers. Complexity of ownership has been mentioned as one of the reasons preventing large-scale action. Rehabilitation schemes involving partial or complete replanting have been undertaken by government agencies but have had little impact. An important obstacle for grove farmers was lack of income during replanting (Hartley, 1988).

Zeven (1972) considered the cultivation of oil palms in groves and on compounds as the semi-domesticated stage; full domestication includes sowing or transplanting seedlings to the field. This practice became the basis of the large-scale oil palm plantation industry of S.E. Asia.

\section{The oil palm in South-East Asia}

The oil palm was introduced to S.E. Asia in the former Dutch East Indies in 1848. Two lots of two palms each were introduced, one lot from Amsterdam and the other lot from Réunion or Mauritius. Their exact origin is not known (Hunger, 1924). The four palms gave rise to the famous Deli dura progeny that formed the backbone of the plantation industry until the late sixties. In the second half of the nineteenth century offspring of these palms was distributed and tested in various botanic and economic gardens throughout the archipelago. The palms did not become immediately a commercial success. However, oil palms were planted on a large scale as ornamentals and lane trees on tobacco estates near Medan, North Sumatra. These palms were found to give higher yields and fruits of better quality than the grove palms of Africa. From 1910 onwards large-scale oil palm planting took place in North 
Sumatra and later also in Peninsular Malaysia. Around 1940 the commercial oil palm area of Sumatra and Malaysia amounted to some 120,000 ha. The current figure is about 3 million ha. The success of oil palm cultivation in S.E. Asia is based on three main factors: 1) the transfer oil palm to a favourable environment, 2) the superior genetic quality of the first imported material and 3) the improved cultivation and processing methods.

\section{Transfer to a favourable environment}

With the transfer of the oil palm from Africa to S.E. Asia, the oil palm was exposed to a more favourable climate. Comparing climatic data from Nigeria (Benin City) and North Sumatra (Medan) rainfall, sunshine duration and maximum temperature appear distinctively different (Figure 1). Although the amount of annual rainfall is comparable at both sites, its distribution is very different. The climate in Benin City is characterised by a dry period from December to February. In Medan monthly rainfall is nearly always above $100 \mathrm{~mm}$, with the exception of February which has a longterm average of $91 \mathrm{~mm}$. In Medan sunshine duration for all months is above 5 hours day ${ }^{-1}$ and for the period February-October even above 6 hours day ${ }^{-1}$.

It was not until the eighties that direct comparisons of oil yields were made between oil palm cultivars planted in both environments. The increase in oil yield upon transfer from Ivory Coast to Indonesia is illustrated in Table 2 with the annual oil yield per hectare of mature palms from the control cross L2TxD10D planted in various breeding trials. In Indonesia oil yields are twice those observed in Africa. The higher oil yield is primarily due to a higher fresh fruit bunch yield (FFB), i.e. production of more bunches per palm rather than an increase in average bunch weight, and also to a higher oil content.

Comparing crop growth rates (CGR) in Malaysia and Nigeria, Corley et al. (1971 a,b) reached the conclusion that in oil palm vegetative dry matter growth (VDM) takes priority over generative growth $(\mathrm{Y})$. This was concluded from the observation

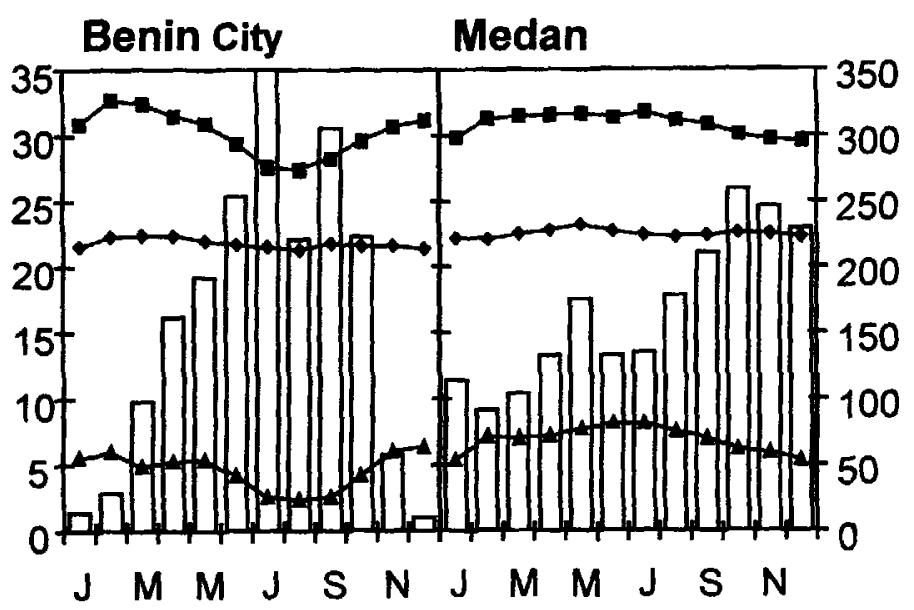

Figure 1. Climatic comparison for Benin City (Nigeria) and Medan (Indonesia). Average monthly minimum (D) and maximum temperatures $(\Delta)\left({ }^{\circ} \mathrm{C}\right)$ and hours of bright sunshine (P) on the left axis, monthly rainfall (bars) (mm) on the right axis. 


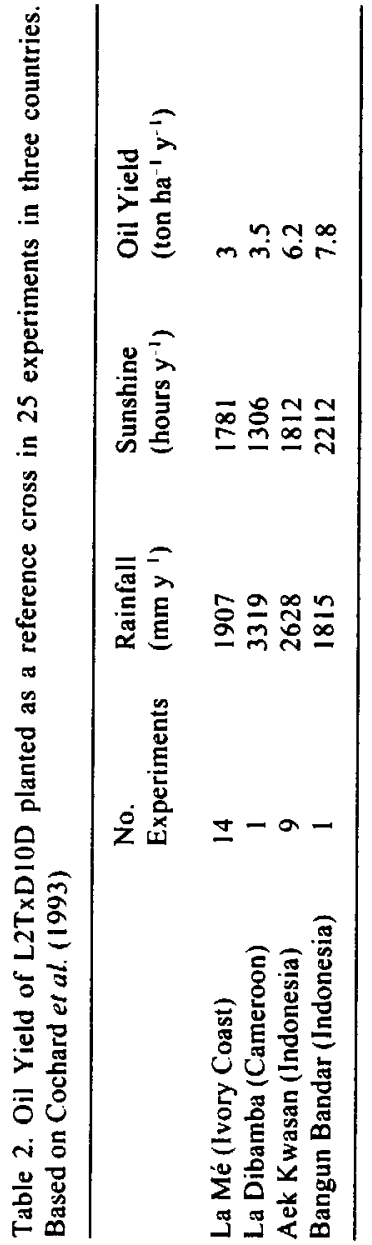

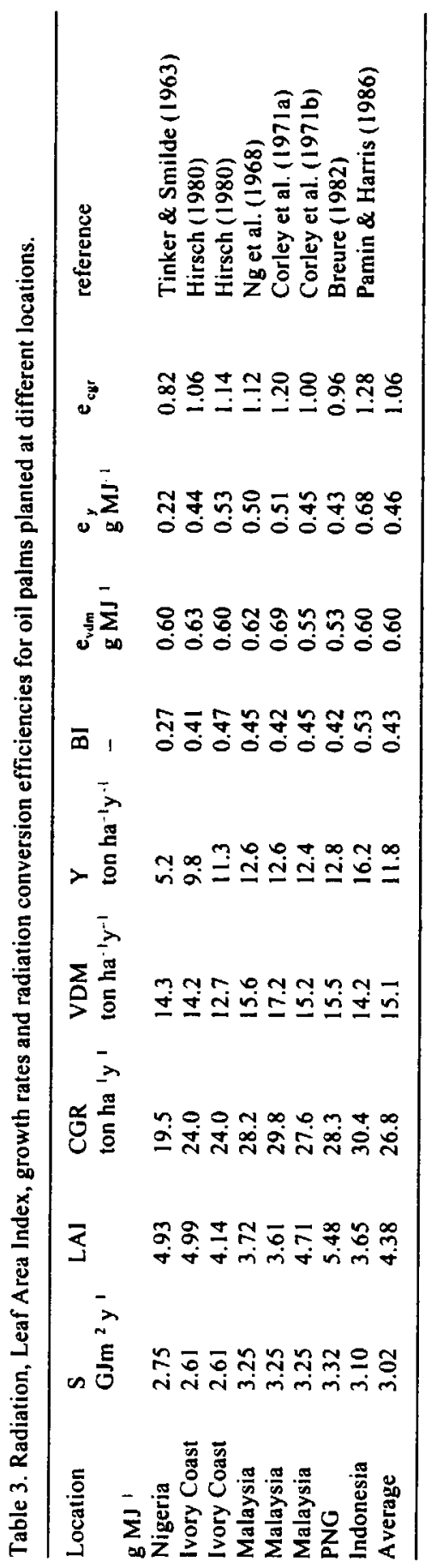

Netherlands Journal of Agricultural Science 45 (1997) 
that VDM per palm remained constant for these two countries whereas $\mathrm{Y}$ differed markedly. It thus seems that only after VDM has been satisfied, the remainder of the assimilates are used for $\mathrm{Y}$. The amount of dry matter partitioned to the bunches per unit time (Bunch Index, BI) was larger under the more favourable conditions in Malaysia. Additional observations in Ivory Coast, Indonesia and Papua New Guinea (PNG) on oil palm growth (Table 3) confirmed the hypothesis that VDM in oil palm is more or less constant irrespective of environmental conditions. Moreover, the VDM per unit intercepted light $\left(e_{\mathrm{vdm}}\right)$ suggests a remarkably constant efficiency of light conversion. On the other hand, the light use efficiency for bunch production $\left(e_{y}\right)$ is much more variable and thus also the efficiency for crop growth $\left(e_{c g r}\right)$. Probably factors other than the amount of intercepted light are limiting bunch yield. These include too little rainfall in Nigeria and to a lesser extent in Ivory Coast or too much in PNG (4000 $\mathrm{mm} \mathrm{y}^{-1}$ ), and a low soil fertility as experienced by Corley et al. (1971a) on inland soils in Malaysia. The most favourable conditions for palm oil production were encountered in an experiment in Indonesia, which showed the highest dry matter production and light use efficiencies (Pamin \& Harris, 1986).

With the transfer to S.E. Asia pests and diseases that reduce oil palm growth and production in Africa such as Coelaenomenodera elaeidis and vascular wilt disease (Fusarium oxysporum) were left behind. The new environment was also favourable in biological respect: up till now no major oil palm diseases have developed in S.E. Asia. This favourable fate was not granted to the transfer of oil palm to South and Central America, where several types of spear rot diseases developed to such an extent that commercial oil palm cultivation is no longer feasible.

An interesting aspect of oil palm growing in the new environment of S.E. Asia is its pollination. It was long assumed that oil palms were wind pollinated, and in areas with low fruit set, assisted pollination was standard practice. It was Syed (1978) who discovered that oil palm in Africa is effectively insect pollinated by Elaeidobius spp. Of the several species, Elaeidobius kamerunicus was imported to Malaysia and PNG in 1982 and later to Indonesia. Initially this has led to peak yields, but also very deep throughs, but after a few years yields stabilised. The main permanent advantage is that the costly assisted pollination is no longer required.

\section{The genotypic advantage and its improvement}

Yield records of the first introductions of oil palm in the former Dutch East Indies are not available (Hunger, 1924). However the yield of the offspring of these palms planted in the economic garden of Bogor in 1878 recorded for the period 1916-1919 amounted about 1.5 ton oil ha-1 $\mathrm{y}^{-1}$ (Van Helten, 1921). Rutgers (1922) recorded the yields of the early commercial plantings in N. Sumatra, and found that oil yields increased from 0.8 ton in the 4th year after planting to about 1.9 tons in the 10th year. Blommendaal (1937) gave as typical yields of Deli dura in N. Sumatra for 12 years and older 2.25 tons of oil per ha- $\mathrm{h}^{-1}$. Compared with yield figures for Africa in those days (Adam, Annet, Chevalier, and Hubert quoted in Van Helten (1921)) of 0.2 to 0.6 tons of oil ha-1 $\mathrm{y}^{-1}$ the figures for $\mathrm{N}$. Sumatra were very favourable. Apart from a larger FFB production the composition of the oil palm fruit in Sumatra was 
much better with $60 \%$ mesocarp and $8 \%$ kernels, against averages of $40 \%$ and $17 \%$ for Africa. The percentage oil in mesocarp varied between $39-64 \%$ in N. Sumatra with an average of $50 \%$.

Breeding progress in the Deli dura population was assessed by comparing the performance of different Deli dura generations in a single experiment planted in Malaysia in 1970 (Hardon et al., 1987). Seeds for this experiment were collected from the palms planted in the economic garden in Bogor in 1878, and from palms planted as lane trees in Tanjung Morawa probably around 1898 (Rutgers, 1922). These two origins are representative for the unselected generations. For the first selections of Deli dura palms seeds were collected at Elmina estate (Malaysia), and for the 4th generations of Deli dura seeds from Banting O.P.R.S. (Malaysia) were used. Results are summarised in Table 4 . In the first generation a major improvement of about $23 \%$ in oil yield was achieved. It was estimated that in further generations a gain of $8-10 \%$ oil yield was achieved.

Corley \& Lee (1994) carried out measurements on the vegetative properties of the palms in this experiment as well. A clear reduction in VDM was achieved. However, the conversion for dry matter production remained constant because in practice a much smaller leaf area was maintained on palms of the 4 th generation. The considerable increase in dry matter conversion for generative organs can be accounted for by the selection and breeding progress.

Further progress in oil palm breeding was achieved with the elucidation of the monogenic inheritance of shell thickness. The heterozygous, thin shelled tenera fruit type has an oil yield that is at least $30 \%$ higher than one of its parents, the homozygous, thick shelled Deli dura. The other parent of the tenera, known as pisifera, is usually female sterile, and cannot therefore be selected on phenotypic performance of its fruits and production. Most oil palm breeding programmes have therefore included progeny testing to identify the best pisifera parents, which has resulted in a further improvement of 9-15\% (Hardon et al., 1987) and has raised the yield levels of the best seedling population in breeding experiments to an FFB production of 40 tons $\mathrm{ha}^{-1}$ and an oil yield approaching 9 tons under Malaysian conditions. As in other perennial crops, higher yields per ha might still be expected from cloning of superior genotypes. Although a suitable cloning technique has been developed for oil palm (Jones, 1974), the cost of vegetative propagation is such that its application is limit-

Table 4. Comparison of unselected sources of Deli dura (Bogor and Tanjung Morawa) with oil palms in the first (Elmina) and fourth (O.P.R.S.) generation of selection. Based on Hardon, et al. (1987) and Corley \& Lee (1992)

\begin{tabular}{llllllll}
\hline Parents & $\begin{array}{l}\text { FFB yield } \\
\text { (ton } \\
\left.\text { ha }^{-1} y^{-1}\right)\end{array}$ & $\begin{array}{l}\text { Mesocarp } \\
\text { per fruit } \\
(\%)\end{array}$ & $\begin{array}{l}\text { Oil per } \\
\text { bunch } \\
(\%)\end{array}$ & $\begin{array}{l}\text { Oil yield } \\
\text { (ton } \\
\left.\text { ha }^{-1} y^{-1}\right)\end{array}$ & $\begin{array}{l}\text { VDM } \\
\text { (ton } \\
\left.\text { ha }^{-1} y^{-1}\right)\end{array}$ & $e_{v d m}$ & $e_{y}$ \\
F, Bogor (1878) & 16.5 & 58.7 & 17.6 & 2.8 & 16.0 & 0.59 & 0.35 \\
Tanjung Morawa (1898) & 16.0 & 59.7 & 17.4 & 2.7 & n.d. & $\begin{array}{l}\text { n.d. } \\
\text { n.d. }\end{array}$ \\
Elmina Estate (1930) & 20.1 & 58.2 & 17.0 & 3.4 & 16.4 & 0.59 & 0.42 \\
Banting O.P.R.S. (1969) & 24.8 & 64.1 & 18.3 & 4.5 & 14.8 & 0.58 & 0.59 \\
\hline
\end{tabular}


ed to breeding programmes and to the production of so called clonal seed, i.e. the production of seeds from clones of selected parents.

\section{Improved cultivation and processing practices}

Comparing the oil yields of the unselected generations in Table 3 with oil yields quoted by Rutgers (1922) and Blommendaal (1937) leads to the conclusion that yields may be improved with at least $40 \%$ by improving cultivation techniques. These improved techniques comprise a whole range of germination, nursery, establishment and maintenance practices. Three practices have particularly contributed to the higher yields. The first is the use of nitrogen fixing leguminous cover crops to protect and improve the soil conditions during the immature phase of the planting (Agamuthu \& Broughton, 1985). The second is the use planting at optimal planting densities for yield in a triangular pattern for an even crown development. The last is fertiliser use. Yield responses of oil palm to fertiliser application are generally very high. This results from the fact that once the nutrient requirements for vegetative growth are fulfilled the additional nutrients will directly benefit bunch production.

Improved processing methods have increased oil extraction rates. In the small scale African setting of fruit processing, efficiency of the extraction rates were in the order of $55 \%$ (Bücher \& Fickendey, 1919). In the early palm oil mills the efficiencies of extraction were raised to $85 \%$ (Blommendaal, 1937) while at present nearly all oil is extracted, with efficiencies approaching $95 \%$.

Although all these factors have individually contributed to the large yield improvement in the plantation industry, the spectacular rise to a level of 5 to 6 tons of oil ha $\mathrm{a}^{-1} \mathrm{y}^{-1}$ on good estates in Malaysia is the result of optimal interaction between improved genotypes and improved cultivation methods in an overall favourable environment.

Clement (1992) considered the oil palm as grown on estates in Malaysia as the 'fully domesticated' stage. Oil palm has become entirely dependent on man for its survival and propagation.

\section{Bridging the yield gap}

In the process of domestication, yield levels are continuously raised (Evans, 1993). We have mentioned the contributions of breeding and improved cultivation. Considering the increase in production from about 0.5 tons of oil ha $\mathrm{h}^{-1} \mathrm{y}^{-1}$ in Nigerian groves to 9 tons for the best experimental plots over an extended period, a great deal has been achieved. Is there still scope for further improvement, and if so, where can the gains be made?

The analyses of Corley (1983) and Henson (1992) showed a theoretical level for potential crop growth rate of oil palm planting of 44 ton ha $\mathrm{a}^{-1} \mathrm{y}^{-1}$ with a corresponding oil production of 17 tons $\mathrm{ha}^{-1} \mathrm{y}^{-1}$. Whether this level is a realistic value for the ceiling of oil palm production in Malaysia remains to be answered. In West Africa, where radiation is much lower than in S.E. Asia the yield potential is reduced ac- 
cordingly. The potential oil yield of 17 tons can be achieved if crop assimilation is increased, respiratory losses are reduced and partitioning of dry matter is improved. The gains to be made with the improvement in each of these three processes should be investigated in the near future with the help of simulation models. Apart from the question how to achieve these higher yields, it remains to be seen whether these yields are economically or ecologically sustainable.

\section{Sustainability of the cropping system}

In our terminology the most advanced stage of domestication involves the cultivation of genetically improved plants under optimised growing conditions. In the long term the ultimate success of domestication depends not only on yield levels attained and product quality but also on the degree in which the resource base, on which the production depends, is left intact. In the past but also at present the establishment of oil palm plantations has been largely at the expense of primary forests, with the obvious loss of biodiversity. Moreover clearing the forest, apart from a massive $\mathrm{CO}_{2}$ release through burning, causes disturbance of the hydrological cycles and nutrient leaching, as a results of reduced transpiration and erosion. Once cover crops are established and at a later stage the palms have formed a closed canopy, soil conditions can be maintained and even improved by judicious fertiliser use. The nutrient and carbon losses which occur when the oil palm needs replanting, can be largely overcome by using zero burning techniques and underplanting methods which are being developed (Henson, 1994). Furthermore reduction of pollution from biocides seems feasible by integrated pest management techniques.

The environmental effects of fruit processing provide another aspect of development of the cropping system. Recent developments involving the return to the field of empty fruit bunches, rather than incinerating them, and the treatment of and use of paim oil mill effluent have greatly reduced the negative effects of large scale oil palm planting and contributed to the recycling of nutrients.

In terms of energy return ratio oil palm is the leading crop with inputs of about 20 $\mathrm{GJ} \mathrm{ha}^{-1} \mathrm{y}^{-1}$ in the form of fertiliser, biocides, fuels and machinery, compared with a ninefold output of about $180 \mathrm{GJ} \mathrm{ha}^{-1} \mathrm{y}^{-1}$. This ratio compares favourable with the average return ratio of 4 established for a wide range of dryland crops, including soybeans as oil producing crop (Evans, 1993). A direct comparison with some other oil producing crops is presented in Table 5.

A final measure of the success of the domestication of oil palm in large-scale monocrop plantations are the economics of the system. A comparison of the average yield of various major oil crops shows that the oil palm by far outyields all other oil crops and that its production costs are only one fifth to one third of other oil crops (Table 5). 
Table 5. Average yields, production costs and energy values of various major oil crops. Based on Basiron \& Darus (1996).

\begin{tabular}{|c|c|c|c|c|c|}
\hline \multirow[b]{2}{*}{ Crop } & \multirow{2}{*}{ 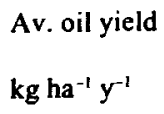 } & \multirow{2}{*}{$\begin{array}{l}\text { Production costs } \\
\text { US\$ ton }\end{array}$} & \multicolumn{3}{|c|}{ Annual energy value $G J \mathrm{ha}^{-1} \mathrm{y}^{-1}$} \\
\hline & & & Input & Output & Ratio \\
\hline Palm oil & 3300 & $225^{41}$ & $19.2^{4)}$ & $182.1^{41}$ & 9.5 \\
\hline Rapeseed & 556 & $1253^{31}$ & $23.0^{51}$ & $70.0^{5)}$ & 3.0 \\
\hline Soybean & 351 & $990^{\prime \prime}$ & $20.0^{\prime \prime}$ & $50.0^{\prime \prime}$ & 2.5 \\
\hline Sunflower & 504 & $698^{21}$ & - & - & - \\
\hline
\end{tabular}

"United States 2) France " Germany "Malaysia ") United Kingdom

\section{New developments}

So far we have looked at factors contributing to the success story of oil palm domestication resulting in plantations and plantation-derived smallholder cropping systems. A number of new developments in oil palm cultivation are taking place that illustrate that the domestication process is still continuing.

Oil palm is now being tested at a substantial scale at high elevations in Malawi and Ethiopia (Blaak \& Stirling, 1996). Encouraging results were obtained from western Ethiopia, where some progenies produced already fruit in the third year after field planting. This recently discovered cold tolerance will possibly enable further distribution of the oil palm beyond the current latitudes. Drought tolerance is a subject that has been much longer under investigation, as it would improve the growing of oil palm in countries with a distinct dry season where oil palm partly originated. Improved physiological techniques could assist breeders in achieving breakthroughs in this area.

By-product utilisation will become increasingly important. As was the case with wood production from rubber trees, it is envisaged that oil palm trunks will be used for a similar purpose. Current practice is that trunks are either shredded, or left in the field to be quickly overgrown with cover crops to reduce infestation with palm beetles. In the established practice the trunks contribute positively to the nutrient balance of oil palm plantings. Another development becoming increasingly important in Ghana is the use of trunks for the production of alcohol. Plantings are cleared at the prime age of 8 to 10 years already, and the trunks are used for tapping of palm wine that is distilled to alcohol.

Harvesting the crop still depends on manual labour and is very labour intensive especially when the palms are tall due to their advanced age. Breeding efforts for reduced height growth may give a solution in the long term. Alternatively planting at a high density and replanting at an early age might be considered. This will increase labour productivity while at each replanting time higher yielding cultivars can be used. 


\section{Conclusions}

In contrast with previous authors on the subject of oil palm domestication (Zeven, 1972, Hartley, 1988 and Clement, 1992) we have arrived at the conclusion that 'full' domestication of the oil palm has not yet been achieved. Transfer of oil palm from its natural West African habitat to a more favourable S.E. Asian environment marked an important step forward in the domestication process. In both environments, however, potential yields of the current plant breeding material have not yet been achieved, while new breeding material is likely to have scope for further yield improvement. Achieving those potential yields with the necessary high input levels is not the final goal. Rather optimal yield levels from economically viable and ecologically sustainable production systems are pursued. Demands for new end-products and for special oils and the development of cultivars for new environments illustrate that the domestication of oil palm is a continuing process.

\section{References}

Agamuthu, P. \& W.J. Broughton, 1985, Nutrient cycling within the developing oil palm - legume ecosystem. Agriculture Ecosystems and Environment 13: 111-123.

Anonymous, 1996. Situation du palmier à huile au Nigeria. OCL, Oléagineux Corps gras Lipides, 3 : 124-125.

Basiron, Y. \& Y. Darus, 1996. The oil palm industry - From pollution to zero waste. The Planter 72: $141-165$.

Blaak, G. \& F. Stirling, 1996. The prospects of extending oil palm cultivation to higher elevations through the using cold-tolerant plant material. The Planter 72: 645-652.

Blommendaal, H.N., 1937. Oil palm cultivation in the Dutch-East Indies (In Dutch) Tjeenk Willink \& Zn., Haarlem, 189 pp.

Breure, C.J., 1982. Factors affecting yield and growth of oil palm tenera in West New Britain. Oléagineux 37: 213-227.

Bücher, H. \& E. Fickendey, 1919. Die Ölpalme. K.F. Koehler, Leipzig, 124 pp.

Clement, C.R., 1992. Domesticated palms. Principes 36: 70-78.

Cochard, B., J.M. Noiret, L. Baudouin, A. Flori \& Ph. Amblard, 1993. Second cycle reciprocal recurrent selection in oil palm Elaeis guineensis Jacq. Results of Deli X La Mé hybrid tests. Oléagineux 48: $441-451$.

Corley, R.H.V., 1983. Potential productivity of tropical perennial crops. Experimental Agriculture, 19: 217-237.

Corley, R.H.V., B.S. Gray, \& S.K. Ng, 1971a. Productivity of the oil palm (Elaeis guineensis Jacq.) in Malaysia. Experimental Agriculture 7: 129-136.

Corley, R.H.V., J.J. Hardon, \& G.Y. Tan, 1971b. Analysis of growth of the oil palm (Elaeis guineensis Jacq.) 1 . Estimating of growth parameters and application in breeding. Euphytica 20: 304-315.

Corley, R.H.V. \& C.H. Lee, 1992. The physiological basis for genetic improvement of oil palm in Malaysia. Euphytica 60: 179-184.

Evans, L.T., 1993. Crop Evolution, Adaptation and Yield, Cambridge University Press, Cambridge, 500 pp.

Hardon, J.J., Corley, R.H.V. \& Lee, C.H., 1987. Breeding and selecting the oil palm. In: A,J. Abott \& R.K. Atkin (Eds.) Improving Vegetatively Propagated Crops. Academic Press Ltd., London, pp. $63-68$.

Harlan, 1975. Of Crops and Man. American Society of Agronomy, Maddison, 295 pp.

Hartley, C.W.S., 1988. The Oil Palm. Tropical Agriculture series, 3rd ed., Longman, Harlow, 761 pp.

Henson, I.E., 1992. Estimating potential productivity of oil palm. In: V. Rao, I.E. Henson, N. Rajanaidu 
(Eds.), Yield Potential in the Oil Palm, Proceedings of the 1990 Int. Workshop on yield potential in the oil palm. PORIM, Kuala Lumpur, pp. 98-108.

Henson, I.E., 1994. Environmental impacts of oil palm plantations in Malaysia. PORIM Occasional Paper No.33, 27 pp.

Hirsch, P.J., 1980. Relations entre l'appareil végetatif et la production chéz le palmier à huile en Côted'Ivoire. Oléagineux 35: 233-239.

Hunger, F.W.T., 1924. The oil palm (Elaeis guineensis), Historical investagation of oil palms in the Dutch East Indies (In Dutch). 2nd. ed., Brill, Leiden, 359 pp.

Johannessen, C.L., 1982. Domestication of Maize continues in Guatemala. Economic Botony 36: 84-99. Jones, L.H., 1974. Propagation of clonal oil palm by tissue culture. The Planter 50: 374-381.

$\mathrm{Ng}$, S.K., S. Thamboo \& P. De Souza, 1968 Nutrient contents of oil palm in Malaya. II. Nutrients in vegetative tissue. The Malaysia Agricultural Journal 46: 332-391.

Pamin, K. \& S.A.Harris, 1986. The effect of planting density and fertilizer on the oil palm. III. Bunch yield (In Indonesian). Bulletin Perkebunan 17: 5-17.

Tinker, P.B.H. \& K.W. Smilde, 1963. Dry matter production and nutrient content of plantation oil palms in Nigeria. II. Nutrient content. Plant and soil 19: 350-363.

Rutgers, A.A.L., 1922. Crop records of oil palms. In: A.A.L. Rutgers (Ed). Investigations on oil palms made at the general experiment station of the AVROS. Ruygrok \& co., Batavia, pp. 100-111.

Seibert, R.J., 1948. The uses of Hevea for food in relation to its domestication. Annals of Missouri Botanic Garden 35: 117-121.

Syed, R.A., 1978. Studies on pollination of oil palm in West Africa and Malaysia. Report, Commonwealth Institute of biological control, 48pp.

Van Helten, H.W., 1921. Communication of the Department of Agriculture, Industry and Trade at Buitenzorg No. 11 (In Dutch). De Indische Mercuur 44: 21-22.

Zeven, A.C., 1967. The semi-wild oil palm and its industry in Africa. Agricultural Research Report, No.689, $178 \mathrm{p}$.

Zeven, A.C., 1972. The partial and complete domestication of the oil palm (Elaeis guineensis Jacq.). Economic Botany 26: 274-279. 